\title{
Implementasi Aplikasi Alumni Berbasis Mobile Application
}

\author{
Chandra Kirana $^{\# 1}$, Risti Wahdaniyah ${ }^{\# 2}$ \\ ${ }^{\text {\#STMIK Atma Luhur Pangkalpinang }}$ \\ Jl. Jend. Sudirman Selindung Lama Pangkalpinang \\ ${ }^{1}$ chandra.kiranalatmaluhur.ac.id \\ ${ }^{2} 1311500025$ emahasiswa.atmaluhur.ac.id
}

\begin{abstract}
Abstrak- Alumni adalah orang-orang yang telah menyelesaikan suatu pendidikan atau yang telah lulus dari sebuah sekolah maupun perguruan tinggi. Dalam suatu perguruan tinggi, alumni memiliki peran yang sangat penting dalam meningkatkan sistem pendidikan, karena pengalaman yang telah mereka dapatkan dapat memberikan masukan serta gagasan baru bagi pembenahan suatu institusi. Saat ini, proses mencari atau menemukan alumni bukanlah suatu hal yang mudah, khususnya mereka alumni angkatan lama, dikarenakan pada waktu mereka lulus belum ada suatu media yang dapat menghubungkan komunikasi sesama alumni, sehingga mengakibatkan komunikasi antara lamuni menjadi terputus. Untuk menangani masalah tersebut, maka dibutuhkan suatu aplikasi yang dapat memberikan informasi serta menjalin hubungan diantara alumni. Aplikasi alumni dibangun dengan menggunakan mobile android. Dengan adanya aplikasi alumni, maka para alumni dapat menjalin hubungan diantara alumni dan dapat saling memberkan informasi.
\end{abstract}

Kata kunci - Alumni, Mobile android, Aplikasi

\section{Pendahuluan}

Alumni adalah lulusan dari sebuah sekolah, akademi, sekolah tinggi, perguruan tinggi atau universitas. Alumni merupakan aset penting yang harus dirangkul dan dikembangkan sedini mungkin. Keberadaan alumni sangatlah berpengaruh pada peningkatan kualitas dari suatu instansi. Ketika alumni bekerja disuatu perusahaan alumni akan membawa nama baik dari sekolah atau unversitas alumni berasal. Selain itu alumni juga dapat membantu almamater mereka dengan memberikan masukan yang bermanfaat atau dengan memberikan informasi lowongan pekerjaan. proses mencari atau menemukan alumni bukanlah suatu hal yang mudah, khususnya mereka alumni angkatan lama, dikarenakan pada waktu mereka lulus belum ada suatu media yang dapat menghubungkan komunikasi sesama alumni, sehingga mengakibatkan komunikasi antara lamuni menjadi terputus. Untuk menangani masalah tersebut, maka dibutuhkan suatu aplikasi yang dapat memberikan informasi serta menjalin hubungan diantara alumni. Aplikasi alumni dibangun dengan menggunakan mobile android. Dengan adanya aplikasi alumni berbasis mobile, maka para alumni dapat menjalin hubungan diantara alumni dan dapat saling memberkan informasi.

Dalam penelitian ini, penulis menggunakan referensi dari beberapa penelitian terdahulu, diantaranya adalah penelitian [1] tentang Sistem Informasi Berbasis Web Untuk Membantu Kegiatan Tracer Study Program Diploma Institut Pertanian Bogor. Penelitian [2] tentang Sistem Informasi Alumni Program Studi Sistem Informasi Universitas Widyatama Berbasis Web. Penelitian [3] tentang Pembangunan Aplikasi Community Messenger Sebagai Alat Interaksi Di Kalangan Generasi C. Penelitian [4] tentang Model Perancangan Aplikasi Penelusuran Alumni Berbasis Website. Penelitian [5] Sms Gateway Sebagai Sarana Informasi Layanan Karier Pada Alumni SMK Teuku Umar Semarang. Penelitian [6] mengenai Pembangunan Aplikasi Pencarian Alumni Berbasis Android dengan Memanfaatkan API Sosial Media. Penelitian [7] mengenai Aplikasi Mobile Alumni Center (Studi Kasus di Institut Sains \& Teknologi AKPRIND).

\section{METODOLOGI PENELITIAN}

\section{A. Analisis Kebutuhan}

Analisis kebutuhan dalam penelitian ini terbagi menjadi kebutuhan fungsional dan kebutuhan non fungsional.

1. Kebutuhan Fungsional Adapun spesifikasi kebutuhan fungsional dalam penelitian ini sebagai berikut:

a) Menyediakan layanan interface untuk mencari informasi yang dapat diakses oleh alumni pada mobile android.

b) Aplikasi dapat memberikan kemudahan kepada alumni dalam menjalin hubungan antar sesama alumni.

2. Kebutuhan Non Fungsional

a) Perangkat Keras: perangkat keras yang digunakan dalam penelitian ini adalah laptop lenovo G40 dengan spesifikasi prosessor Intel Core i3, 6 GB RAM dan HDD 500GB.

b) Perangkat Lunak: perangkat lunak yang digunakan dalam penelitian ini adalah sistem 
operasi Windows 7 Ultimate 64-bit, Android eclpise, Notepad ++, XAMPP 1.7.2.

\section{B. Langkah Penelitian}

Langkah penelitian dalam penelitian ini antara lain:

1. Studi literatur: Mencari referensi ilmu yang berhubungan dengan penelitian ini yaitu almuni.

2. Analisis kebutuhan: Analisis kebutuhan dilakukan untuk mendapatkan suatu informasi yang dibutuhkan oleh pengguna, dalam hal ini adalah alumni.

3. Pengumpulan data: pengumpulan data dilakukan untuk mengetahui data apa saja yang dibutuhkan dalam penelitian ini.

4. Rancangan Aplikasi: merancang aplikasi yang akan digunakan oleh para almuni.

5. Pembuatan Aplikasi: membuat sebuah tampilan antarmuka yang akan digunakan untuk membangun aplikasi dengan cara melakukan pengkodean.

6. Pengujian Aplikasi: Pengujian dilakukan untuk melihat apakah aplikasi yang dibangun telah memenuhi dari analisis kebutuhan yang ada.

7. Analisis Hasil Pengujian: Analisis dilakukan pada tahapan pengujian serta validasi untuk mengetahui apakah aplikasi sudah berjalan sesuai yang diharapkan.

8. Penarikan Kesimpulan: Pengujian yang telah dilakukan akan ditarik sebuah kesimpulan apakah aplikasi yang telah dibangun sesuai dengan yang diharapkan.

\section{Use Case Diagram}

Use Case Diagram menggambarkan funsionalitas dari sebuah sistem. Use Case Diagram hanya memberikan gambaran singkat antara use case, pengguna, dan juga sistem[8]. Berikut merupakan Use Case Diagram didalam penelitian ini yang digambarkan pada gambar 1 .

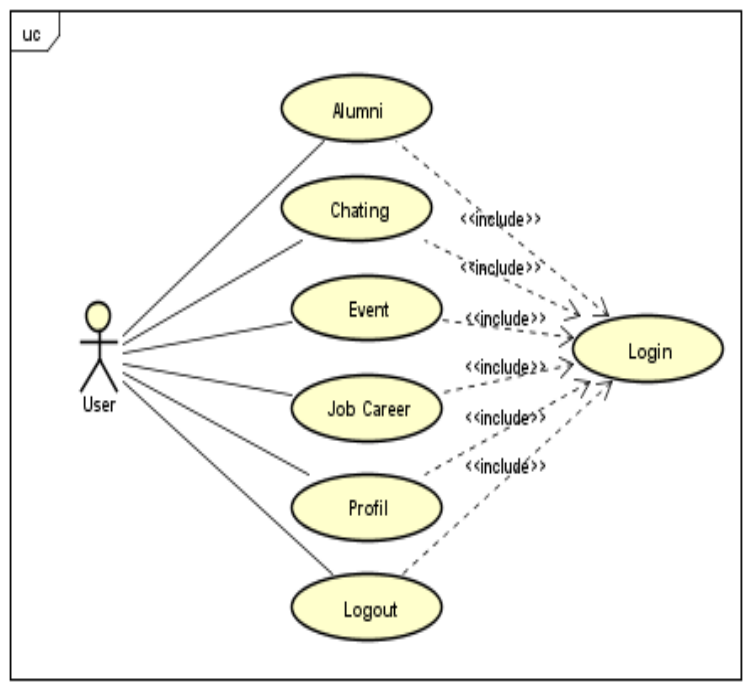

Gambar 1. Use case diagram
Proses pertama adalah alumni memilih menu alumni untuk menampilkan data-data dari alumni. Kedua, alumni memilih chating untuk melakukan komunikasi antar sesama alumni. Ketiga, alumni memilih menu event untuk melihat kegiatan atau perlombaan, Keempat, alumni memilih menu job career untuk melihat lowongan pekerjaan. Kelima, alumni memilih menu profil untuk melihat data diri alumni itu sendiri. Keenam, alumni memilih menu logout untuk keluar dari aplikasi.

\section{Activity Diagram}

Activity Diagram menggambarkan berbagai alir aktivitas didalam sebuah sistem yang sedang dirancang, bagaimana masing-masing alir berawal, decision yang mungkin terjadi dan bagaimana mereka berakhir[8]. Berikut merupakan activity diagram yang digambarkan pada gambar 2 .

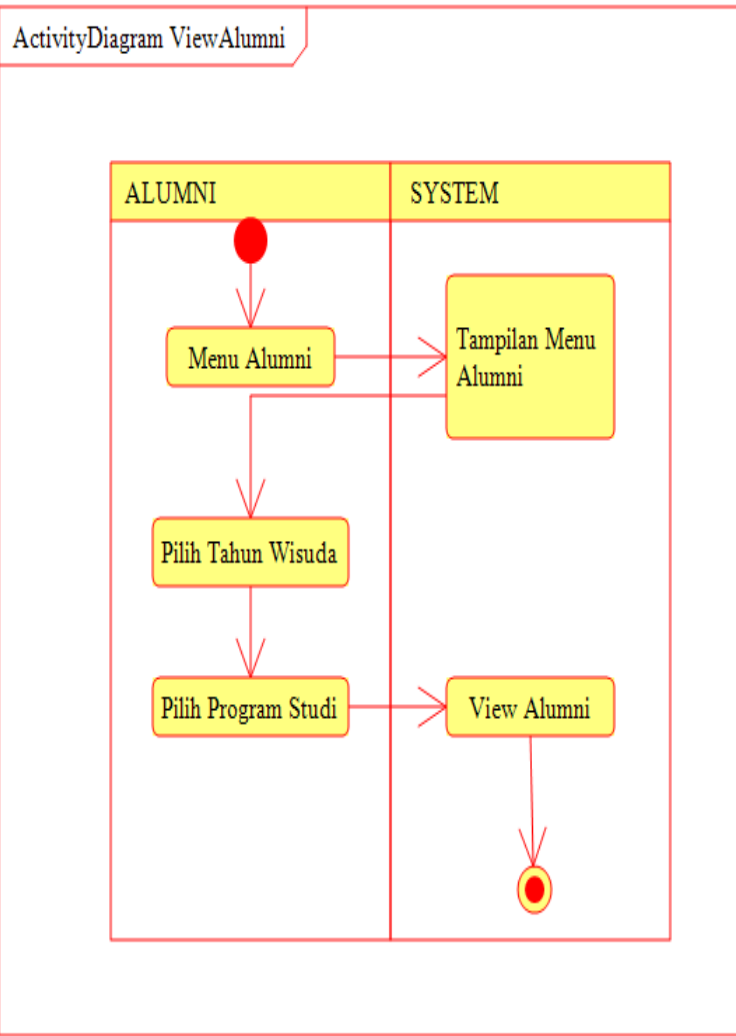

Gambar 2. Activity diagram

Gambar 2 activity diagram alumni untuk melihat daftar alumni dengan memilih tahun wisuda dan program studi selanjutnya daftar alumni ditampilkan.

\section{E. Class Diagram}

Class Diagram merupakan adalah sebuah spesifikasi yang jika diinstansiasi akan menghasilkan sebuah objek dan merupakan inti dari pengembangan dan desain berorientasi objek. Class diagram digunakan untuk menampilkan kelas - kelas di dalam suatu system[8]. 


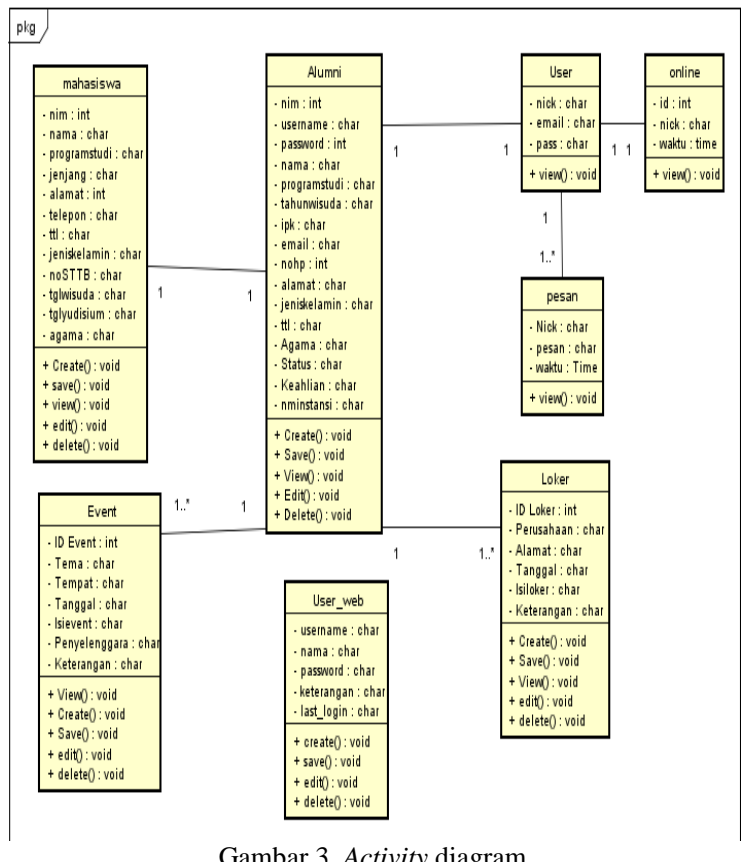

Aplikasi alumni berbasis mobile android memiliki beberapa kelas yaitu: Mahasiswa, Alumni, User, Pesan, Event, Loker.

\section{F. Sequence Diagram}

Sequence Diagram merupakan diagram yang menjelaskan interaksi objek berdasarkan urutan waktu. Sequence diagram menggambarkan urutan atau tahapan yang harus dilakukan pengguna[8]. Berikut sequence diagram yang digambarkan pada gambar 4.

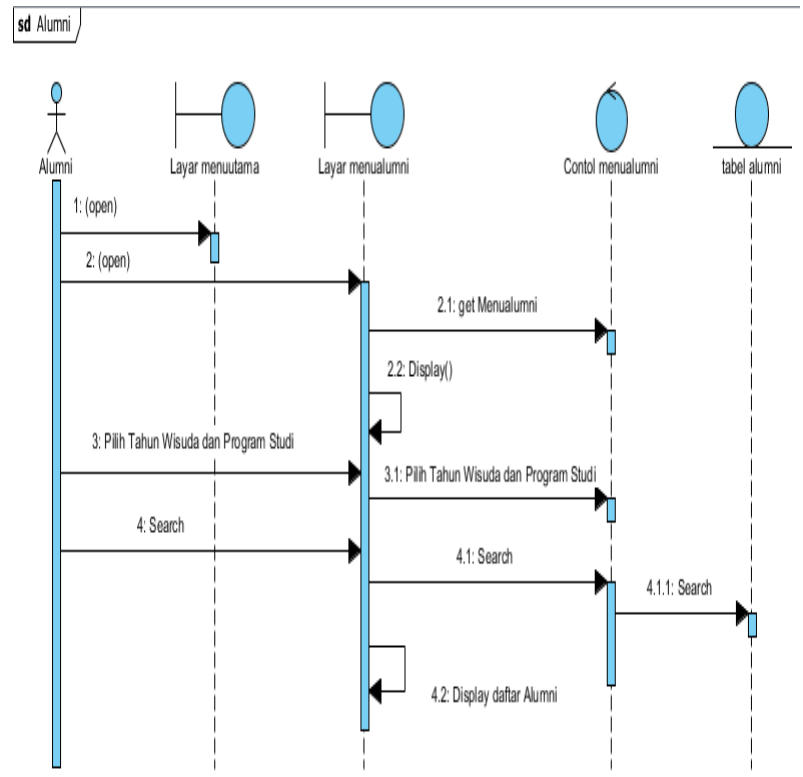

Gambar 4. Sequence diargam
Gambar 4 Sequence diagram alumni menggambarkan proses alumni sebagai client untuk mencari dan melihat daftar alumni.

\section{HASIL DAN ANALISIS}

\section{A. Hasil Perancangan}

Aplikasi Alumni yang dibangun merupakan suatu aplikasi berbasis Mobile Android. Dibangunnya aplikasi alumni bertujuan sebagai suatu media yang dapat menghubungkan komunikasi antar alumni, baik angkatan lama maupun angkatan baru. Berikut ini merupakan tampilan dari aplikasi alumni berbasis mobile android yang digambarkan pada gambar 5, gambar 6, dan gambar 7.

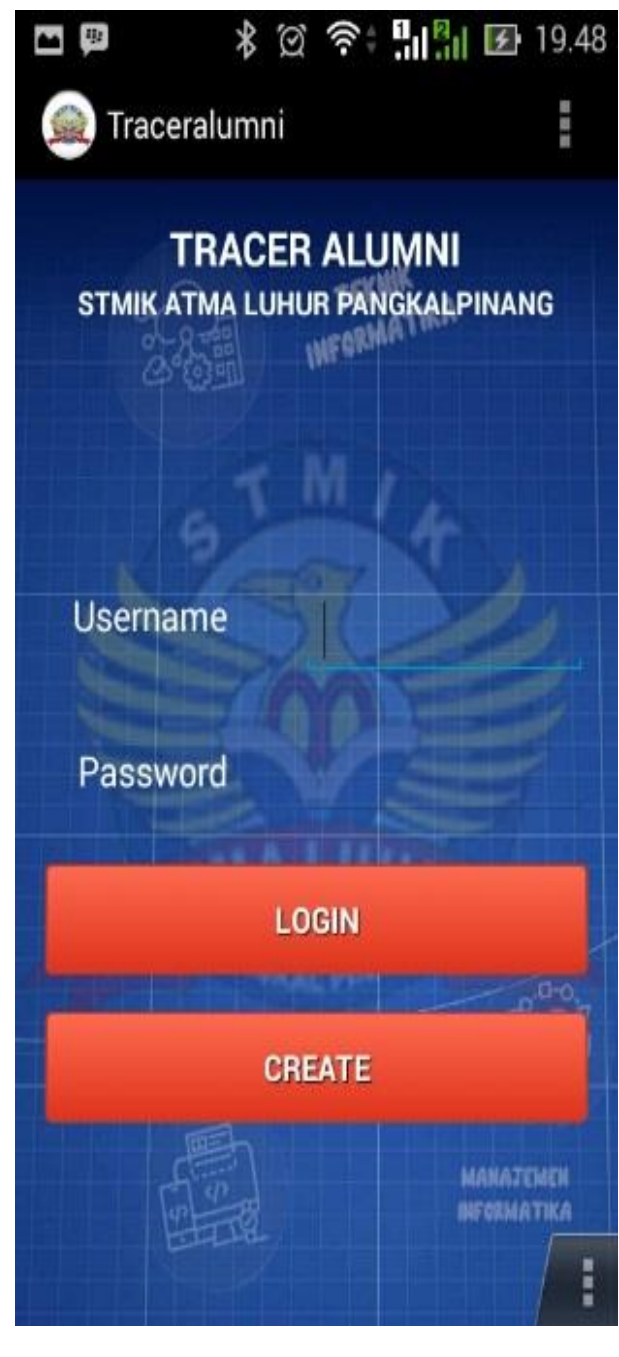

Gambar 5. Tampilan login 


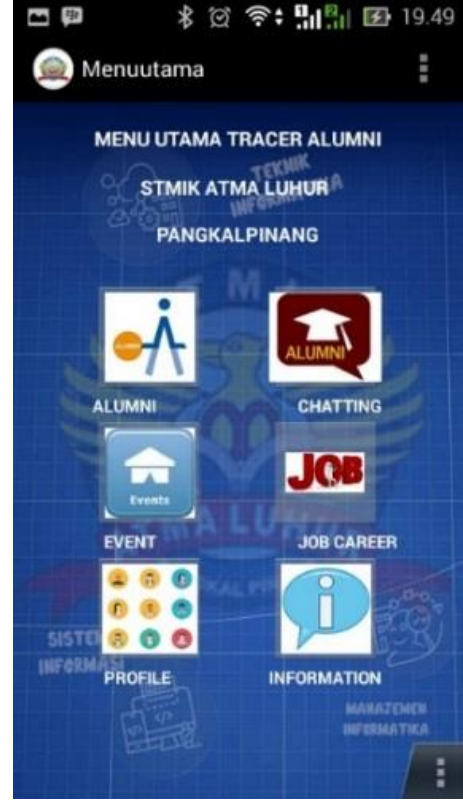

Gambar 6. Tampilan menu utama

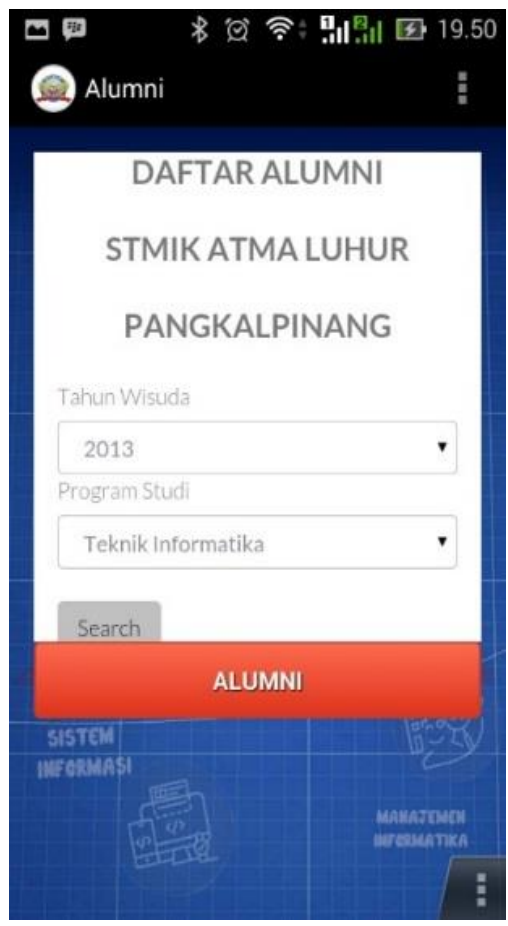

Gambar 7. Tampilan menu alumni

\section{B. Hasil Pengujian}

Pengujian dalam penelitian ini menggunakan pengujian blackbox. Pengujian dilakukan untuk melihat sesuai atau tidaknya fungsi dari aplikasi yang telah dibangun. Langkah-langkah pengujian adalah sebagai berikut:

1. Memasang file apk pada setiap perangkat

2. Menjalankan aplikasi.

3. Uji tombol menu yang terdapat pada menu utama.

4. Mengamati keberhasilan aplikasi alumni yang telah dibangun.

TABEL I

HASIL PENGUJIAN BLACKBOX

\begin{tabular}{|c|c|c|c|c|}
\hline No. & $\begin{array}{c}\text { Fungsi } \\
\text { yang diuji }\end{array}$ & Cara Pengujian & $\begin{array}{l}\text { Hasil yang } \\
\text { diharapkan }\end{array}$ & $\begin{array}{c}\text { Hasil } \\
\text { Pengujian }\end{array}$ \\
\hline & $\begin{array}{l}\text { Halaman } \\
\text { Login }\end{array}$ & $\begin{array}{l}\text { Pada aplikasi } \\
\text { ini } \\
\text { menampilkan } \\
\text { halaman login } \\
\text { untuk masuk } \\
\text { sebagai alumni. }\end{array}$ & \begin{tabular}{l}
\multicolumn{2}{l}{ Menampilkan } \\
halaman login \\
dan berhasil \\
masuk $r$ ke \\
dalam menu \\
utama aplikasi \\
alumni.
\end{tabular} & OK \\
\hline & $\begin{array}{l}\text { Halaman } \\
\text { Create } \\
\text { Alumni }\end{array}$ & $\begin{array}{l}\text { Membuat } \\
\text { account untuk } \\
\text { bisa masuk ke } \\
\text { dalam aplikasi. }\end{array}$ & $\begin{array}{l}\text { Dapat login } \\
\text { menggunakan } \\
\text { account yang } \\
\text { telah di buat. }\end{array}$ & $\mathrm{OK}$ \\
\hline & $\begin{array}{l}\text { Search } \\
\text { Alumni }\end{array}$ & $\begin{array}{lr}\text { Memilih menu } \\
\text { alumni yang } \\
\text { ada di aplikasi } \\
\text { yang } \\
\text { dimenu utama, } \\
\text { mencari daftar } \\
\text { alumni } \\
\text { bedasarkan } \\
\text { tahun wisuda } \\
\text { dan program } \\
\text { studi. } \\
\end{array}$ & \begin{tabular}{lr}
\multicolumn{2}{l}{ Menampilkan } \\
semua daftar \\
alumni sesuai \\
dengan tahun \\
wisuda dan \\
program studi \\
yang dipilih.
\end{tabular} & $\mathrm{OK}$ \\
\hline & Chatting & $\begin{array}{l}\text { Memilih menu } \\
\text { chatting pada } \\
\text { menu utama } \\
\text { dan daftar } \\
\text { member alumni } \\
\text { untuk chatting. }\end{array}$ & $\begin{array}{l}\text { Mempilkan } \\
\text { ruang chatting } \\
\text { dan mulai } \\
\text { chatting } \\
\text { setelah } \\
\text { terdaftar. }\end{array}$ & $\mathrm{OK}$ \\
\hline & $\begin{array}{l}\text { Create } \\
\text { Event }\end{array}$ & $\begin{array}{l}\text { Pada aplikasi } \\
\text { ini alumni } \\
\text { memilih menu } \\
\text { create event } \\
\text { dan isi event. }\end{array}$ & $\begin{array}{l}\text { Menampilkan } \\
\text { form create } \\
\text { event dan } \\
\text { membuat } \\
\text { event. }\end{array}$ & $\mathrm{OK}$ \\
\hline & $\begin{array}{l}\text { View } \\
\text { Event }\end{array}$ & $\begin{array}{l}\text { Pada aplikasi } \\
\text { ini alumni } \\
\text { memilih menu } \\
\text { view event. }\end{array}$ & $\begin{array}{l}\text { Menampilkan } \\
\text { daftar event } \\
\text { yang telah di } \\
\text { buat. }\end{array}$ & $\mathrm{OK}$ \\
\hline & $\begin{array}{l}\text { Create Job } \\
\text { Career }\end{array}$ & $\begin{array}{l}\text { Pada aplikasi } \\
\text { ini alumni } \\
\text { memilih menu } \\
\text { create loker } \\
\text { dan isi loker. }\end{array}$ & $\begin{array}{l}\text { Menampilkan } \\
\text { form create } \\
\text { loker dan } \\
\text { membuat } \\
\text { loker. }\end{array}$ & $\mathrm{OK}$ \\
\hline & $\begin{array}{l}\text { View Job } \\
\text { Career }\end{array}$ & $\begin{array}{l}\text { Pada aplikasi } \\
\text { ini alumni } \\
\text { memilih menu } \\
\text { view loker. }\end{array}$ & $\begin{array}{l}\text { Menampilkan } \\
\text { daftar loker } \\
\text { yang telah di } \\
\text { buat. }\end{array}$ & $\mathrm{OK}$ \\
\hline & Profile & $\begin{array}{l}\text { Pada aplikasi } \\
\text { ini alumni } \\
\text { memilih menu } \\
\text { profie dan klik } \\
\text { button view. }\end{array}$ & $\begin{array}{l}\text { Menampilkan } \\
\text { tabel profile } \\
\text { yang telah di } \\
\text { buat. }\end{array}$ & $\mathrm{OK}$ \\
\hline & Infomation & $\begin{array}{l}\text { Pada aplikasi } \\
\text { ini alumni } \\
\text { memilih menu } \\
\text { information. }\end{array}$ & $\begin{array}{l}\text { Menampilkan } \\
\text { informasi. }\end{array}$ & OK \\
\hline
\end{tabular}




\section{KESIMPULAN}

Berdasarkan hasil pengembangan sistem yang telah dilakukan dapat diambil kesimpulan sebagai berikut:

1. Berdasarkan pengujian blackbox, aplikasi dapat berjalan pada perangkat mobile android dengan baik.

2. Aplikasi ini dapat memberikan data terkait alumni yang lulus pada setiap tahunnya dan sesuai dengan program studi dengan adanya menu alumni yang disediakan.

3. Aplikasi ini menyediakan fitur ruang chatting grup bagi alumni sebagai sarana penghubung antara sesama alumni.

4. Dengan dibuatnya aplikasi ini maka alumni dapat langsung menyampaikan informasi sehingga informasi dapat mudah tersampaikan kepada alumni dan yang membutuhkan informasi terkait alumni karena tidak perlu menunggu pihak ketiga memberikan informasi alumni (placement office), karena dapat diakses menggunakan internet.

\section{REFERENSI}

[1] Indriasari, Sofiyanti., 2012, Sistem Informasi Berbasis Web Untuk Membantu Kegiatan Tracer Study Program Diploma Institut Pertanian Bogor, Jurnal Sains Terapan, Edisi II , Vol-2 hal : $84-102$.

[2] Utama Kalza, Charisma., 2012, Sistem Informasi Alumni Program Studi Sistem Informasi Universitas Widyatama Berbasis Web, Skripsi, Program Studi Sistem Informasi Fakultas Teknik, Universitas Widyatama, Bandung .

[3] Nugroho, Aryo., Al Azam, Moh Noor., Anam, Syamsul., 2016, Pembangunan Aplikasi Community Messenger Sebagai Alat Interaksi Di Kalangan Generasi C, Narodroid, Vol. 2, No.2.

[4] Effendy, Dedi Usman., dan Suswanto, Budyi., 2013, Model Perancangan Aplikasi Penelusuran Alumni Berbasis Website, Jurnal Dinamika Dotcom Vol. 5 No. 1.

[5] Adhita, Rizal,. 2011, SMS Gateway Sebagai Sarana Informasi Layanan Karier Pada Alumni SMK Teuku Umar Semarang, Skripsi, Program Studi Teknik Informatika, Universitas Dian Nuswantoro, Semarang.

[6] Astomo, Dikot Sugeng, 2017, Pembangunan Aplikasi Pencarian Alumni Berbasis Android dengan Memanfaatkan API Sosial Media, Skripsi. Program Studi Teknik Informatika Fakultas Teknik dan Ilmu Komputer, Bandung.

[7] Sulistyorini, Prastuti. 2009. Pemodelan Visual dengan Menggunakan UML dan Rational Rose. Jurnal Teknologi Informasi DINAMIK Volume XIV, No. 1, STMIK Widya Pratama Pekalongan.

[8] Fatkhiyah,Erfanti, dkk, 2016, Aplikasi Mobile Alumni Center (Studi Kasus di Institut Sains \& Teknologi AKPRIND), Jurnal SCRIPT Vol.3 No. 2. 